\title{
INFLUENCE OF DROPLET SIZE ON SPRAY DEPOSITION AND WEED CONTROL USING GLYPHOSATE
}

\author{
Osmar G. T. M. Oliveira ${ }^{1}$, Paulo R. M. Lopes ${ }^{2}$, Carlos G. Raetano ${ }^{3}$, \\ Ronaldo C. Lima², Evandro P. Prado ${ }^{2 *}$ \\ ${ }^{2 *}$ Corresponding author. Universidade Estadual Paulista "Júlio de Mesquita Filho"/ Faculdade de Ciências Agrárias e \\ Tecnológicas/ Dracena - SP, Brasil. E-mail: evandro.prado@unesp.br | ORCID ID: https://orcid.org/0000-0001-7616-0471
}

\section{KEYWORDS}

dose response, application technology, chemical control, spray deposits.

\begin{abstract}
Droplet size is one of the most important factors that affect spray deposition and weed control through the use of herbicides. The aim of this study was to evaluate the influence of the droplet size on the spray deposition and control of Euphorbia heterophylla and Urochloa ruziziensis by using glyphosate. The treatments included spraying glyphosate with fine, medium, coarse, very coarse, and ultra-coarse droplet sizes to determine the deposition, uniformity of distribution, visual control, and dry weight reduction (DWR). The treatments were compared with the values of the dose required to achieve 50\% DWR or 50\% visual control (C50) at 7, 14, 21, and 28 days after herbicide application. Fine and medium droplet sizes afforded high deposition values and low distribution uniformities in E. heterophylla. Fine and medium droplet sizes yielded the lowest C50 on visual control and DWR in E. heterophylla, respectively. The droplet size did not affect the spray deposition on $U$. ruziziensis plants; however, the larger droplets had less uniformity of distribution. In $U$. ruziziensis plants, spraying glyphosate with coarse and medium droplet sizes yielded the lowest values of C50 to visual control and DWR, respectively.
\end{abstract}

\section{INTRODUCTION}

Chemical control is an essential practice for obtaining high yields in agricultural exploration, especially for intensive crops; however, its success is related to the quality of herbicide application.

Pesticide application programs are aimed at maximizing the amount of active ingredients deposited on the desired target, with uniform coverage to provide efficient control, and minimizing deposition in an off-target location. In most cases, meeting these requirements is challenging, as most applications are performed by fractionating the liquid into droplets, which can move away from the target (Grella et al., 2020).

The safe and environmentally friendly application of efficient and economical pesticides is a major concern and challenge for the agricultural sector, because pesticides can negatively impact non-target organisms (Dereumeaux et al., 2020). Thus, the optimization of these applications is essential for the efficient management of herbicides (Butts et al., 2018, 2019).
The analysis of the quantity and quality of the biologically active products deposited on the target is the first step toward successful herbicide management. Droplet size can influence the performance of biological control, depending on the herbicide and the morphological characteristics of the target (Ruas et al., 2011; Ferguson et al., 2018, 2019).

The deposition of the active ingredient on the targets can be optimized by the correct selection of spray nozzle (Ferguson et al., 2015; Farias et al., 2020). Nozzles are the main components of a spraying system and directly affect the efficiency of pesticides (Nuyttens et al., 2007). Many growers are skeptical of spray nozzles that spray coarse droplets, in addition to providing lower drift losses (Ferguson et al., 2015, 2016; Balsari et al., 2019) which helps reduce environmental contamination (Grella et al., 2020). However, coarse droplets may provide satisfactory control of some weed species if certain herbicides are used (Ferguson et al., 2018, 2019).

\footnotetext{
${ }^{1}$ Universidade Estadual Paulista "Júlio de Mesquita Filho"/ Faculdade de Engenharia/ Ilha Solteira - SP, Brasil.

${ }^{2}$ Universidade Estadual Paulista "Júlio de Mesquita Filho"/ Faculdade de Ciências Agrárias e Tecnológicas/ Dracena - SP, Brasil.

${ }^{3}$ Universidade Estadual Paulista "Júlio de Mesquita Filho"/ Faculdade de Ciências Agronômicas/ Botucatu - SP, Brasil.
} 
Coarse droplets cannot easily adhere to plant parts. They also provide a low coverage rate due to the tendency to ricochet (Balsari et al., 2017; Duga et al., 2017) or to fragment on impact with the leaf surface (Boukhalfa et al., 2014). This can lead to a decrease in the biological efficiency of the herbicides as the droplet size increases (Knoche, 1994; Smith et al., 2000; Creech et al., 2015), even for mobile herbicides such as glyphosate.

To address the disadvantages arising due to the drift process involving small droplets, researchers working in the field of Pesticide Application have attempted to optimize the control efficiency loss limit by increasing the droplet size. Thus, this topic has attracted significant research attention. It is hypothesized that glyphosate herbicide, which performs a systemic action, can offer satisfactory control efficiency even when applied in larger droplets, which are less prone to drift losses.

Therefore, the aim of this study was to evaluate the influence of droplet size on the spray deposition and control efficiency of Euphorbia heterophylla and Urochloa ruziziensis through the use of glyphosate.

\section{MATERIAL AND METHODS}

The experiments were conducted between April and October 2019 in a greenhouse at the Sao Paulo State
University - College of Agricultural and Technological Sciences, Dracena Campus (latitude 21 $27^{\prime \prime}$ S, longitude $51^{\circ} 33^{\prime \prime} \mathrm{W}$, and average altitude $373 \mathrm{~m}$ ).

Approximately five seeds each of E. heterophylla and $U$. ruziziensis (different pots) were sown at a depth of 0.5 to $1 \mathrm{~cm}$ in $0.8 \mathrm{~L}$ plastic pots $(8 \mathrm{~cm} \times 8 \mathrm{~cm} \times 14 \mathrm{~cm})$, with a potting mixture of sandy loam soil ( $81 \%$ sand, $7 \%$ silt, and $12 \%$ clay; $\mathrm{pH} 4.6)$ and substrate Carolina Soil ${ }^{\circledR}(3: 1 \mathrm{w} / \mathrm{w})$. After sowing, automatic micro-sprinkler irrigation was performed daily according to the plant needs. Seven days after emergence (DAE), the seedlings for each species were thinned to one uniformly sized plant per pot.

Nutritional supplementation was provided at 14 DAE for $U$. ruziziensis plants only, using $2.0 \mathrm{~g}$ per pot of a formulated mineral fertilizer (04-14-08). Furthermore, 4-5 leaves of E. heterophylla and 2-3 tillers of $U$. ruziziensis were sprayed. The choice of weed species is justified because they are morphologically distinct targets (monocotyledonous and dicotyledonous).

\section{Quantification of spray deposition}

The spray deposition values were analyzed in a completely randomized design using five treatments (fine, medium, coarse, very coarse, and ultra-coarse droplets), with 40 replicates each, represented by the pots of each plant species. A description of the treatments is shown in Table 1.

TABLE 1. Treatments used in spraying E. heterophylla and U. ruziziensis plants.

\begin{tabular}{cccccc}
\hline Treatments & Spray Nozzle & $\begin{array}{c}\text { Nozzle } \\
\text { angle/flow }\end{array}$ & $\begin{array}{c}\text { Pressure } \\
(\mathrm{kPa})\end{array}$ & $\begin{array}{c}\text { Droplet } \\
\text { class }^{\mathrm{a}}\end{array}$ & $\begin{array}{c}\text { Droplet size }^{\mathrm{b}} \\
\text { (micrometer) }^{(145-225)}\end{array}$ \\
\hline T1 & XR & 11002 & 200 & $\mathrm{~F}$ & $(145-325)$ \\
T2 & XR & 11002 & 100 & $\mathrm{M}$ & $(226-400)$ \\
T3 & TT & 11002 & 200 & $\mathrm{C}$ & $(326-400)$ \\
T4 & AIXR & 11002 & 200 & VC & $(401-500)$ \\
T5 & TTI & 11002 & 200 & UC & $(>650)$ \\
\hline
\end{tabular}

${ }^{\mathrm{a} D r o p l e t ~ s i z e ~ i n f o r m a t i o n ~ w a s ~ p r o v i d e d ~ b y ~ t h e ~ m a n u f a c t u r e r s . ~}{ }^{\mathrm{b}} \mathrm{ASABE}$ S-572.1; Classification (2009). F: fine, M: medium, C: coarse, VC: very coarse, UC: ultra-coarse.

Treatments were applied using a pressurized $\mathrm{CO}_{2}$ back sprayer (Herbicat $\left.{ }^{\circledR}\right)$, equipped with 4 nozzles spaced at $0.50 \mathrm{~m}$ apart travelling at $5.0 \mathrm{~km} \mathrm{~h}^{-1}$ for all treatments except for $\mathrm{T} 2$ which travelling at $3.5 \mathrm{~km} \mathrm{~h}^{-1}$, delivering a spray volume of approximately $156 \mathrm{~L} \mathrm{ha}^{-1}$. The nozzles (Table 1) were held at a distance of $0.5 \mathrm{~m}$ from the top of the plants. The spray deposition values were determined using a spray solution of $1.5 \mathrm{~g} \mathrm{~L}^{-1}$ Brilliant Blue dye FCF (Brastókio ${ }^{\circledR}$ ) and $2.5 \mathrm{~L} \mathrm{ha}^{-1}\left(925 \mathrm{~g}\right.$ ae ha $\left.{ }^{-1}\right)$ glyphosate (Roundup $\mathrm{DI}^{\circledR}$ ). Glyphosate was added to the spray solution to cater for the possible physicochemical modification provided by the herbicide, which could influence spray deposition.

After treatment application and drying of the solution (approximately $5 \mathrm{~min}$ ), the plants were cut at a position above the ground, placed in plastic bags, and washed with $100 \mathrm{~mL}$ of deionized water to remove the dye. The solution containing the dye was placed in $70 \mathrm{~mL}$ plastic containers and stored in the dark until absorbance determination. After washing, the plants were placed in paper bags and oven-dried at $65{ }^{\circ} \mathrm{C}$ for $72 \mathrm{~h}$, and the dry weight (DW) was determined using an analytical balance (Marten, model AY220).
The amount of dye deposited on the plants was quantified using a spectrophotometer (Biospectrum, model SP 220) at a wavelength of $630 \mathrm{~nm}$ (Prado et al., 2015; Nairn \& Forster, 2019; Godinho Jr., 2020). A linear equation was established ([dye] $=7.235 \times \mathrm{Abs}+0.0263 ; \mathrm{R}^{2}$ $=0.99$ ) using the previously known dye concentrations of $15,7.5,3.75,1.875,0.9375,0.4688$ and $0.2343 \mathrm{mg} \mathrm{L}^{-1}$, which allowed for the transformation of the absorbance values into dye concentrations (in $\mathrm{mg} \mathrm{L}^{-1}$ ).

Using the dye concentration values in the solution, dye concentration detected by the spectrophotometer, and sample dilution volume, the volume retained by the target could be established.

$$
\mathrm{V} 1=\frac{\mathrm{C} 2 \times \mathrm{V} 2}{\mathrm{C} 1}
$$

Where:

$\mathrm{C} 1=$ initial dye concentration in the spray solution $\left(\mathrm{mg} \mathrm{L}^{-1}\right)$;

V1 $=$ volume retained on the target $(\mathrm{mL})$;

$\mathrm{C} 2=$ concentration detected by the spectrophotometer $\left(\mathrm{mg} \mathrm{L}^{-1}\right)$,

$\mathrm{V} 2=$ sample dilution volume $(\mathrm{mL})$. 
The volume retained by each plant $(\mathrm{mL})$ was transformed into microliters and divided by its respective DW to obtain the volume in $\mu \mathrm{L} \mathrm{g}^{-1} \mathrm{DW}$. The deposition data were submitted to analysis of variance and means compared by the Scott-Knott test at $5 \%$ probability.

To determine the uniformity of spray deposition distribution for each treatment, the data obtained were standardized, ordered, and used to calculate the normal probability distribution (Gaussian distribution) using the formula $\int_{-\infty}^{x} \frac{1}{\sqrt{2 \pi}} e^{\left(-\frac{x^{2}}{2}\right)}$. The data were used to adjust logistic regression using [eq. (2)].

$$
Y=\frac{a}{1+e^{b-c x}}
$$

Where:

\author{
a: maximum curve asymptote; \\ $\mathrm{b}$ : curve displacement along the $\mathrm{x}$ axis (value in \\ modulus); \\ c: curve slope, \\ $\mathrm{x}$ : deposition data.
}

To represent the cumulative distribution frequency of spray deposition, we adopted an approximate value of 1 for the maximum curve asymptote. In general, the displacement of the curve along the $\mathrm{x}$-axis is represented by the module of parameter " $b$," and the inflection point is represented by the parameter "c." Logistic accuracy was assessed using the determination coefficient $\left(\mathrm{R}^{2}\right)$. The data were analyzed using $\mathrm{R}$ statistical software (R Development Core Team, 2017).

Dose-response curves for $E$. heterophylla and $U$. ruziziensis when sprayed with glyphosate herbicide with different droplet sizes

The dose-response curves of the plants were determined in a completely randomized experimental design using a $5 \times 8$ factorial scheme, with five spray droplet size classes (fine, medium, coarse, very coarse, and ultra-coarse) and eight herbicide concentrations, totaling to 40 treatments. These treatments were applied in quadruplicate for E. heterophylla and U. ruziziensis.

Considering a glyphosate label dose of $925 \mathrm{~g}$ ae ha ${ }^{-1}$ (Roundup Original DI) to control E. heterophylla and $U$. ruziziensis, the eight concentrations used were $0,11,34$, $103,308,925,2.775$ and $8.325 \mathrm{~g}$ ae ha ${ }^{-1}$. The spraying was carried out using the same equipment and operating conditions used in the spray deposition experiment, except for the use of a spray boom with two spray nozzles spaced $0.5 \mathrm{~m}$ apart. A description of the treatments (spray tips) is presented in Table 1. After treatment application, the pots were placed in a greenhouse for $24 \mathrm{~h}$ without irrigation. Subsequently, they were irrigated based on the plant needs.

At 7, 14, 21, and 28 days after application (DAA) of the glyphosate, visual evaluations of the control percentage were carried out based on vigor, chlorosis, necrosis, and plant death. The evaluation results were compared to those of the control treatment (without herbicide application). Using these data, scores were assigned using a scale ranging from $0 \%$, when there was no phytotoxic effect, to $100 \%$, when the plants were dead.

After the last control evaluation (28 DAA), the plants of each species were harvested at a position above the ground, placed in a paper bag, and oven-dried at $65{ }^{\circ} \mathrm{C}$ for $72 \mathrm{~h}$. The DW was determined using an analytical balance (Marten, model AY220).

The DW data were transformed into dry weight reduction (DWR) data by comparison with control treatment data according to [eq. (3)]:

$$
\mathrm{DWR}=\left(\frac{\mathrm{C}-\mathrm{T}}{\mathrm{C}}\right) \times 100,
$$

Where:

$$
\begin{aligned}
& \text { DWR: dry weight reduction; } \\
& \text { C: mean of the four-control DW, } \\
& \text { T: individual DW of plants treated with glyphosate. }
\end{aligned}
$$

Data percentages for visual control and DWR were analyzed using a non-linear regression to determine the amount of glyphosate needed to provide $50 \%$ of visual control or 50\% DWR for E. heterophylla and U. ruziziensis. A four-parameter log-logistic equation (Equation 4) was used (Ritz et al., 2015).

$$
\mathrm{Y}=\frac{\mathrm{D}-\mathrm{C}}{1+\exp \{\mathrm{b}[\log (\mathrm{X})-\log (\mathrm{C} 50)]\}}+\mathrm{C}
$$

Where:
Y: plant response;
$\mathrm{X}$ : herbicide dose $(\mathrm{g}$ ae ha-1);
D: curve upper limit;
C: curve lower limit;
b: curve slope of C50,

C50: dose $\left(\mathrm{g}\right.$ ae ha $\left.{ }^{-1}\right)$ required to reduce $50 \%$ of DW or provide $50 \%$ of visual control.

The analysis of the dose-response curve and determination of the C50 values were performed using the drc package in $\mathrm{R}$ software ( $\mathrm{R}$ Development Core Team, 2017). The ANOVA function was used to perform the lackof-fit test, and a P-value $\geq 0.05$ was considered an acceptable description of the data by the fitted non-linear model (Ritz \& Streibig, 2012; Ritz et al., 2015).

\section{Meteorological conditions at the time of application}

Meteorological data of temperature, air relative humidity, and wind speed were recorded during the four application scenarios, as listed in Table 2. The data were recorded by an automatic meteorological station (Campbell Scientific Datalogger-model CR10X) installed approximately $300 \mathrm{~m}$ away from the application site. 
TABLE 2. Meteorological conditions at the time of spraying during the deposition and dose-response experiments.

\begin{tabular}{lcccc}
\hline Meteorological data & DE & DU & DRE & DRU \\
\hline Temperature $\left({ }^{\circ} \mathrm{C}\right)$ & $31 \pm 3$ & $27 \pm 3$ & $23 \pm 2$ & $28 \pm 2$ \\
Relative humidity $(\%)$ & $54 \pm 5$ & $60 \pm 5$ & $50 \pm 5$ & $40 \pm 5$ \\
$*$ Wind speed $\left(\mathrm{km} \mathrm{h}^{-1}\right)$ & 2 & 5 & 3 & 3 \\
Application date & $15 / 03 / 18$ & $10 / 05 / 19$ & $26 / 06 / 19$ & $29 / 07 / 19$ \\
\hline
\end{tabular}

*Maximum wind speed recorded at a weather station outside the greenhouse. Source: Campbell Scientific Automatic Meteorological Station, Datalogger CR10X model - FCAT/Unesp, Dracena-SP, 2019. DE: Deposition E. heterophylla/ DU: Deposition U. ruziziensis/ DRE: Dose response E. heterophylla/ DRU: Dose response U. ruziziensis.

\section{RESULTS AND DISCUSSION}

\section{Spray deposition quantification}

Spray deposition values of E. heterophylla and $U$. ruziziensis plants, sprayed with glyphosate associated with the Brilliant Blue dye with different droplet sizes are provided in Table 3.

TABLE 3. Deposition values on Euphorbia heterophylla and Urochloa ruziziensis, expressed in microliters per gram of the dry weight (DW), after spraying with different droplet sizes.

\begin{tabular}{ccc}
\hline \multirow{2}{*}{ Droplet size } & E. heterophylla & U. ruziziensis \\
\cline { 2 - 3 } & \multicolumn{2}{c}{ Spray deposits $\left(\mu \mathrm{L} \mathrm{g}^{-1} \mathrm{DW}\right)$} \\
\hline Fine & $77.2 \mathrm{a}$ & $152.5 \mathrm{a}$ \\
Medium & $82.0 \mathrm{a}$ & $154.9 \mathrm{a}$ \\
Coarse & $51.0 \mathrm{~b}$ & $146.7 \mathrm{a}$ \\
Very coarse & $55.7 \mathrm{~b}$ & $162.3 \mathrm{a}$ \\
Ultra-coarse & $46.1 \mathrm{~b}$ & $163.6 \mathrm{a}$ \\
\hline
\end{tabular}

Means followed by the same letter do not differ from each other according to the Scott-Knott test at 5\% probability.

High spray deposition values were observed on $E$. heterophylla plants when sprays with fine and medium droplets were used. These values which differed significantly (F: 42.1; P < 0.001; CV: 25.0\%) from treatments with coarse, very coarse, and ultra-coarse droplets (Table 3). Tokura et al. (2013) reported high deposition values on E. heterophylla plants when spraying was carried out using very fine and fine droplets and using lower values for very coarse droplets, corroborating the results obtained (Table 3).

The higher deposition values observed when spraying fine and medium droplets on E. heterophylla is probably associated with the characteristics of plant leaves with high epicuticular wax content, high laticifer density, and large adaxial surface cuticle thickness (Ferreira et al., 2003). Leaf surfaces with high wax content are difficult to wet, making droplet retention difficult due to a greater probability of bounce or shatter after impact on the leaf surface (Smith et al., 2000; Massinon et al., 2017), especially for those with larger diameters (Smith et al., 2000).

There was no significant difference $(\mathrm{F}=0.85, \mathrm{P}=$ $0.492, \mathrm{CV}=30.7 \%)$ in the spray deposition on $U$. ruziziensis plants for the different droplet sizes (Table 3).
Similar results were reported in a study by Rodrigues-Costa et al. (2012). This previous study did not find significant differences in the deposition on Brachiaria plantaginea plants at the 3-5 tiller stage, which were sprayed with different spray nozzles and droplet sizes, delivering a spray volume of 150 and $200 \mathrm{~L} \mathrm{ha}^{-1}$. Furthermore, Tokura et al. (2013) did not find a significant difference in the spray deposition on B. plantaginea plants between fine, medium, and very coarse droplet sizes sprayed by flat fan nozzles.

Distinct spray deposition results were observed between the two weed species studied (Table 3). The major factors affecting leaf droplet retention are the morphological characteristics of the plants, pesticide formulation, and characteristics of the spray process, such as the droplet size and velocity (Smith et al., 2000; Creech et al., 2015; Massinon et al., 2017), which can result in different results depending on the combination.

The parameter estimates for the logistic model that describes the deposition of the spray solution on $E$. heterophylla and $U$. ruziziensis are presented in Table 4. Apart from the fine droplets on U. ruziziensis, all other droplet sizes produced a uniformity coefficient equal to or greater than 0.92 , demonstrating a good curve fit. 
TABLE 4. Parameter estimates for the logistic model, describing spray deposition on E. heterophylla and $U$. ruziziensis plants, when sprayed with different droplet sizes.

\begin{tabular}{|c|c|c|c|c|c|c|c|c|c|c|}
\hline \multirow{3}{*}{$\begin{array}{l}\text { Equation } \\
\text { parameters }^{\mathrm{a}}\end{array}$} & \multicolumn{10}{|c|}{ Droplet size } \\
\hline & \multicolumn{2}{|c|}{ Fine } & \multicolumn{2}{|c|}{ Medium } & \multicolumn{2}{|c|}{ Coarse } & \multicolumn{2}{|c|}{ Very coarse } & \multicolumn{2}{|c|}{ Ultra-coarse } \\
\hline & $\mathrm{E}$ & $\mathrm{U}$ & $E$ & $\mathrm{U}$ & E & $\mathrm{U}$ & E & $\mathrm{U}$ & E & U \\
\hline $\mathrm{a}$ & 1.01 & 1.00 & 1.01 & 1.01 & 1.01 & 1.01 & 1.01 & 1.01 & 1.01 & 1.01 \\
\hline $\mathrm{b}$ & 6.71 & 5.88 & 6.60 & 5.54 & 6.62 & 5.23 & 7.41 & 5.02 & 6.46 & 5.17 \\
\hline $\mathrm{c}$ & 0.085 & 0.038 & 0.080 & 0.036 & 0.110 & 0.035 & 0.100 & 0.031 & 0.139 & 0.031 \\
\hline $\mathrm{R}^{2}$ & 0.98 & 0.86 & 0.96 & 0.94 & 0.96 & 0.92 & 0.97 & 0.94 & 0.95 & 0.94 \\
\hline
\end{tabular}

E: Euphorbia heterophylla; U: Urocloa ruziziensis

${ }^{\mathrm{a}} \mathbf{Y}=\frac{\mathbf{a}}{\mathbf{1}+\mathbf{e}^{\mathbf{b}-\mathbf{c x}}}$

Greater uniformity of spray deposition distribution was observed in E. heterophylla plants when sprayed with ultra-coarse droplets, evidenced by the highest value of the "c" parameter (0.139), followed by coarse (0.110), very coarse (0.100), fine (0.085) and medium (0.080) droplets (Table 4). Good distribution uniformity of the herbicide solution on weeds is fundamental for greater control effectiveness. Non-uniform deposition implies that plants receive less or more deposition than required. Inadequate deposition of the herbicide solution on plants can result in control failures. However, an amount above the desired dose will result in wastage and increase the risk of environmental contamination.

The highest values of the "c" parameter for $U$. ruziziensis (Table 4) were observed in treatments involving fine droplets (0.038), followed by medium (0.036), coarse

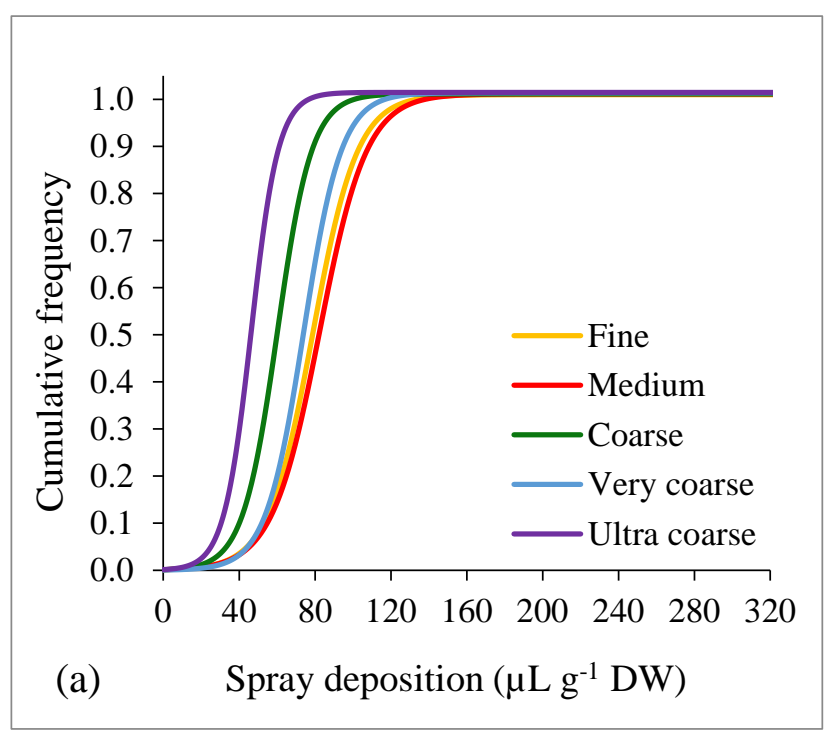

(0.035), very coarse, and ultra-coarse (0.031). Lower distribution uniformity on both weeds was observed in treatments that received the highest deposition values, regardless of the droplet size (Tables 3 and 4). The increase in variability was related to the higher mean deposition values in these treatments.

The accumulated frequency of deposition on $E$. heterophylla and $U$. ruziziensis plants sprayed with different droplet sizes is shown in Figure 1. Figure 1a shows a greater curve slope in treatments with coarse and very coarse droplets (higher "c" parameter in Table 4), when compared to the curves of fine and medium droplet sizes in $E$. heterophylla. For $U$. ruziziensis, the greatest curve slopes were obtained for the treatments with the smallest droplet sizes (Figure 1b).

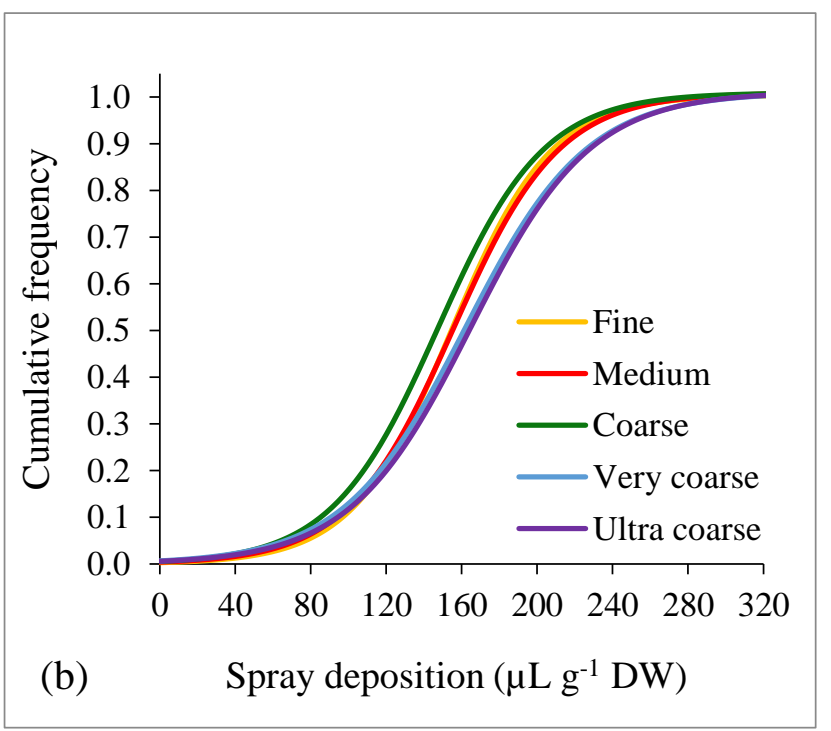

FIGURE 1. Cumulative frequency of spray deposition $\left(\mu \mathrm{L} \mathrm{g}^{-1} \mathrm{DW}\right)$ provided by different droplet sizes on E. heterophylla (a) and $U$. ruziziensis (b) plants, using the logistic model.

Although the curves from treatments with very coarse and ultra-coarse droplets provided better uniformity of spray deposition on E. heterophylla plants (Figure 1), these treatments yielded the lowest spray deposition values (Table 3). This is evident when observing the curves of fine and medium droplets, which are placed to the right of the very coarse and ultra-coarse droplet size curves (Figure 1a).
Therefore, it was found that the increase in the droplet size resulted in higher deposition values for E. heterophylla but with a lower uniformity deposition.

The cumulative frequency curves obtained for $U$. ruziziensis plants presented similar shapes, and the curves for treatments applied with smaller droplets were slightly sloped compared to those with very coarse and ultra-coarse droplet sizes (Figure 1b). 
Likewise, Costa et al. (2008) also reported less uniformity and greater deposition of the spray solution on Brachiaria brizantha plants, when sprayed with air induction nozzles with extremely coarse droplets. The uniformity of spray solution deposition is highlighted as a relevant factor in the performance of pesticides (RodriguesCosta et al., 2012), since an insufficient amount of deposition on the target can result in control failures.

Dose-response curves for $E$. heterophylla and $U$. ruziziensis when sprayed with glyphosate herbicide with different droplet sizes
According to the results of the lack-of-fit test ( $\mathrm{P}>$ $0.05 ; \mathrm{F}$ test), there were no significant differences in the DWR curves and percentage of visual control for $E$. heterophylla (Table 5) and U. ruziziensis, except for the visual assessment at 7 DAA (Table 6), with P values $>0.05$, indicating satisfactory model fit (Ritz \& Streibig, 2012; Ritz et al., 2015).

The estimates of the parameters obtained from the log-logistic regression that describes the visual control and DWR of E. heterophylla plants when glyphosate was applied in different droplet sizes are described in Table 5.

TABLE 5. Log-logistic regression parameters and C50 values $( \pm$ SE) that describe the visual control and dry weight reduction in E. heterophylla plants sprayed with glyphosate of different droplet sizes.

\begin{tabular}{|c|c|c|c|c|c|c|}
\hline \multirow{2}{*}{ DAA } & \multirow{2}{*}{ Parameters } & \multicolumn{5}{|c|}{ Droplet size } \\
\hline & & Fine & Medium & Coarse & Very coarse & Ultra-coarse \\
\hline \multirow{6}{*}{7} & & \multicolumn{5}{|c|}{ Visual control $(\%)$} \\
\hline & $\mathrm{B}$ & -2.5 & -1.4 & -2.5 & -1.8 & -12.6 \\
\hline & $\mathrm{C}$ & 0.52 & 0.52 & 0.52 & 0.52 & 0.52 \\
\hline & $\mathrm{D}$ & 56.5 & 56.5 & 56.5 & 56.5 & 56.5 \\
\hline & $\mathrm{C} 50$ & $612(74)$ & $784(121)$ & $777(99)$ & $1134(150)$ & $1069(186)$ \\
\hline & Lack of fit & & & 0.856 & & \\
\hline \multirow{5}{*}{14} & B & -4.2 & -3.1 & -3.1 & -3.4 & -6.5 \\
\hline & $\mathrm{C}$ & 1.2 & 1.2 & 1.2 & 1.2 & 1.2 \\
\hline & $\mathrm{D}$ & 92.3 & 92.3 & 92.3 & 92.3 & 92.3 \\
\hline & $\mathrm{C} 50$ & $500(35)$ & $764(41)$ & $656(37)$ & $747(42)$ & $969(106)$ \\
\hline & Lack of fit & \multicolumn{5}{|c|}{$0.9008(\mathrm{NS})$} \\
\hline \multirow{5}{*}{21} & $\mathrm{~B}$ & -3.1 & -2.6 & -2.3 & -1.8 & -2.8 \\
\hline & $\mathrm{C}$ & 0.8 & 0.8 & 0.8 & 0.8 & 0.8 \\
\hline & $\mathrm{D}$ & 101.2 & 101.2 & 101.2 & 101.2 & 101.2 \\
\hline & $\mathrm{C} 50$ & $430(24)$ & $520(30)$ & $516(31)$ & $662(44)$ & $618(36)$ \\
\hline & Lack of fit & \multicolumn{5}{|c|}{$0.8466(\mathrm{NS})$} \\
\hline \multirow{5}{*}{28} & B & -3.8 & -1.7 & -1.6 & -2.5 & -2.5 \\
\hline & $\mathrm{C}$ & 1.8 & 1.8 & 1.8 & 1.8 & 1.8 \\
\hline & $\mathrm{D}$ & 101.9 & 101.9 & 101.9 & 101.9 & 101.9 \\
\hline & $\mathrm{C} 50$ & $444(63)$ & $539(80)$ & $612(93)$ & $558(71)$ & $737(89)$ \\
\hline & Lack of fit & \multicolumn{5}{|c|}{$0.8854(\mathrm{NS})$} \\
\hline \multirow{6}{*}{28} & & \multicolumn{5}{|c|}{ Dry weight reduction $(\%)$} \\
\hline & $\mathrm{B}$ & -0.5 & -0.5 & -0.7 & -0.6 & -1.2 \\
\hline & $\mathrm{C}$ & 1.3 & 1.3 & 1.3 & 1.3 & 1.3 \\
\hline & $\mathrm{D}$ & 91.7 & 91.7 & 91.7 & 91.7 & 91.7 \\
\hline & $\mathrm{C} 50$ & $49(12)$ & $38(10)$ & $58(13)$ & $107(24)$ & $225(30)$ \\
\hline & Lack of fit & \multicolumn{5}{|c|}{$0.9941(\mathrm{NS})$} \\
\hline
\end{tabular}

Note. C50 is the glyphosate dose required to provide 50\% visual control or 50\% dry weight reduction. DAA: days after application. DWR: Dry weight reduction NS: not significant

Very coarse and ultra-coarse droplet sizes yielded the highest $\mathrm{C50}$ values for the visual control of $E$. heterophylla plants in all periods evaluated. The same behavior was observed in the DWR with higher C50 values for ultra-coarse droplet applications (Table 5).
As observed in Table 5, the C50 values increased with an increase in droplet size. In the DWR, there was an almost 6-fold increase between the treatments with medium (38 $\left.\mathrm{g} \mathrm{ae} \mathrm{ha}^{-1}\right)$ and ultra-coarse $\left(225 \mathrm{~g}\right.$ ae ha $\left.{ }^{-1}\right)$ droplet sizes. It is evident that glyphosate visual control in E. heterophylla plants can be compromised by spraying very coarse and 
ultra-coarse droplets. The increase in C50 values for visual control may be related to the smaller deposition provided by the larger diameter droplets (Table 3). Thus, spray application aimed at controlling E. heterophylla with an ultra-coarse droplet size, even when using systemic herbicides such as glyphosate, should be avoided because of the possibility of failure.

Since fine droplets are more prone to drift (Ferguson et al., 2015, 2016; Balsari et al., 2019) there is a possibility of spraying the herbicide glyphosate with (a) larger droplets on the borders of the area to be treated, especially when they are adjacent to areas cultivated with susceptible species and (b) smaller droplets inside the crop area where adverse effects of drift can be minimized (Stainier et al., 2006). Thus, other parameters, such as the application volume, adjuvant tank mixtures, herbicides, and meteorological conditions at the time of spraying, must be considered when choosing the appropriate droplet size.

The estimates of the parameters obtained from the log-logistic regression that describes the visual control and DWR of $U$. ruziziensis plants when glyphosate was applied in different droplet sizes are described in Table 6.

TABLE 6. Log-logistic regression parameters and C50 values $( \pm$ SE) that describe the visual control and dry weight reduction in $U$. ruziziensis plants sprayed with glyphosate of different droplet sizes.

\begin{tabular}{|c|c|c|c|c|c|c|}
\hline \multirow{2}{*}{ DAA } & \multirow{2}{*}{ Parameters } & \multicolumn{5}{|c|}{ Droplet size } \\
\hline & & Fine & Medium & Coarse & Very coarse & Ultra-coarse \\
\hline \multirow{6}{*}{7} & & \multicolumn{5}{|c|}{ Visual control (\%) } \\
\hline & B & -4.8 & -3.7 & -1.3 & -3.6 & -5.1 \\
\hline & $\mathrm{C}$ & -0.1 & -0.1 & -0.1 & -0.1 & -0.1 \\
\hline & $\mathrm{D}$ & 95.5 & 95.5 & 95.5 & 95.5 & 95.5 \\
\hline & $\mathrm{C} 50$ & $367(47)$ & $318(15)$ & $167(17)$ & $287(15)$ & $309(10)$ \\
\hline & Lack of fit & & & & & \\
\hline \multirow{5}{*}{14} & B & -2.7 & -2.2 & -1.5 & -3.2 & -7.8 \\
\hline & $\mathrm{C}$ & -0.5 & -0.5 & -0.5 & -0.5 & -0.5 \\
\hline & $\mathrm{D}$ & 95.3 & 95.3 & 95.3 & 95.3 & 95.3 \\
\hline & C50 & $275(21)$ & $228(21)$ & $108(13)$ & 219(19) & $272(22)$ \\
\hline & Lack of fit & \multicolumn{5}{|c|}{$\mathrm{P}=0.0534(\mathrm{NS})$} \\
\hline \multirow{5}{*}{21} & $\mathrm{~B}$ & -1.9 & -2.0 & -4.3 & -3.9 & -6.9 \\
\hline & $\mathrm{C}$ & -0.2 & -0.2 & -0.2 & -0.2 & -0.2 \\
\hline & $\mathrm{D}$ & 95 & 95 & 95 & 95 & 95 \\
\hline & C50 & $196(20)$ & $177(18)$ & $75(9)$ & $157(17)$ & $252(51)$ \\
\hline & Lack of fit & \multicolumn{5}{|c|}{$\mathrm{P}=1.0000(\mathrm{NS})$} \\
\hline \multirow{5}{*}{28} & B & -1.9 & -2.4 & -5.0 & -2.8 & -3.3 \\
\hline & $\mathrm{C}$ & -0.5 & -0.5 & -0.5 & -0.5 & -0.5 \\
\hline & $\mathrm{D}$ & 99.6 & 99.6 & 99.6 & 99.6 & 99.6 \\
\hline & $\mathrm{C} 50$ & $166(20)$ & $143(15)$ & $68(12)$ & $144(15)$ & $215(24)$ \\
\hline & Lack of fit & \multicolumn{5}{|c|}{$\mathrm{P}=1.0000(\mathrm{NS})$} \\
\hline \multirow{6}{*}{28} & & \multicolumn{5}{|c|}{ Dry weigh reduction $(\%)$} \\
\hline & $\mathrm{B}$ & -3.3 & -2.9 & -6.8 & -1.3 & -1.5 \\
\hline & $\mathrm{C}$ & -0.3 & -0.3 & -0.3 & -0.3 & -0.3 \\
\hline & $\mathrm{D}$ & 72.0 & 72.0 & 72.0 & 72.0 & 72.0 \\
\hline & $C 50$ & $158(30)$ & $73(13)$ & $94(22)$ & $155(40)$ & $149(35)$ \\
\hline & Lack of fit & \multicolumn{5}{|c|}{$\mathrm{P}=0.8912(\mathrm{NS})$} \\
\hline
\end{tabular}

Note. C50 is the glyphosate dose required to provide 50\% visual control or 50\% dry weight reduction. DAA: days after application. DWR: Dry weight reduction NS: not significant

In U. ruziziensis plants, the lowest C50 values of the visual control were found with coarse droplet size applications for all the evaluated periods (Table 6). For the DWR, lower C50 values were observed when medium ( $73 \mathrm{~g}$ ae ha $\left.^{-1}\right)$ and coarse (94 $\mathrm{g}$ ae $\mathrm{ha}^{-1}$ ) droplets were applied. In contrast, spraying of fine and ultra-coarse droplets yielded higher C50 values (Table 6). Therefore, the use of fine droplets is evidently not the most suitable technique for $U$. ruziziensis control, since lower control and drift losses may occur, especially under unfavorable meteorological conditions. 
Although no significant differences in spray deposition were detected in $U$. ruziziensis plants, the lowest C50 values found with medium and coarse droplets may have occurred because of other factors not observed in this study, or because the herbicide phytotoxicity is not related to the amount of spray deposition on the plants. It should be noted that the deposition study was carried out at different periods from the control study, and morphological plant characteristics may have varied with the environmental conditions.

A higher C50 value obtained with a reduced DW of $U$. ruziziensis plants when sprayed with fine droplets may be related to the meteorological conditions at the time of application (Table 2), especially at low relative humidity $(40 \pm 5 \%)$, which may have provided less wetness time on the leaves and consequently decreased herbicide absorption and translocation.

Similar results were reported by Ferguson et al. (2019), who observed a higher dry weight reduction of Chloris spp. when sprayed with coarse droplets. Ferguson et al. (2018) also reported greater weed control efficacy for a broad group of herbicide modes of action using coarse droplets, in addition to reducing the potential risk of drift compared to fine droplet sprays.

When aiming for good control performance ( $\geq 80 \%)$ of $E$. heterophylla and $U$. ruziziensis plants while minimizing drift losses simultaneously, the use of nozzles that provide coarse droplets may be a suitable for glyphosate application. It is noteworthy that the spray volume applied in this study was $156 \mathrm{~L} \mathrm{ha}^{-1}$ and spraying coarse droplets in reduced spray volumes may decrease coverage and the efficacy of glyphosate. Butts et al. (2018) found reductions in the effectiveness of weed control with increasing droplet diameter in the herbicides dicamba and glufosinate, especially in smaller volumes. The same authors reported the extreme complexity of the herbicide application process, with multiple variables impacting its effectiveness.

Finally, there seems to be no consensus in choosing the ideal droplet size, as there are many variables, such as the species of plants, herbicide mode of action, plant resistance to the herbicide, and meteorological conditions at the application time, among others that can play, individually or in combination, a relevant role in weed control. New studies must be conducted to improve the understanding of this process.

\section{CONCLUSIONS}

Fine and medium droplet sizes afforded the highest deposition values and the lowest distribution uniformity in $E$. heterophylla plants. Spraying glyphosate on E. heterophylla plants using fine and medium droplet sizes yielded the lowest C50 values for visual control and DWR, respectively.

Droplet size did not interfere with spray deposition on $U$. ruziziensis plants, but larger droplet sizes yielded low distribution uniformity. In $U$. ruziziensis plants, spraying glyphosate with coarse and medium droplet sizes afforded the lowest C50 values for visual control and DWR, respectively.

\section{ACKNOWLEDGEMENTS}

The authors would like to thank the Fundação de Pesquisa do Estado de São Paulo (FAPESP- processo: 2019/00533-5) for financial support.

\section{REFERENCES}

ASABE. American Society of Agricultural and Biological Engineers (2009) Spray nozzle classification by Droplet Spectra. Standard 572.1. St Joseph, American Society of Agricultural and Biological Engineers.

Balsari P, Gil E, Marucco P, Van de Zande JC, Nuyttens D, Herbst A, Gallart M (2017) Field-crop-sprayer potential drift measured using test bench: Effects of boom height and nozzle type. Biosystems engineering 154: 3-13. DOI: https://doi.org/10.1016/j.biosystemseng.2016.10.015

Balsari P, Grella M, Marucco P, Matta F, Miranda-Fuentes A (2019) Assessing the influence of air speed and liquid flow rate on the droplet size and homogeneity in pneumatic spraying. Pest management science 75(2): 366379. DOI: https://doi.org/10.1002/ps.5120

Boukhalfa HH, Massinon M, Belhamra M, Lebeau F (2014) Contribution of spray droplet pinning fragmentation to canopy retention. Crop Protection 56: 9197. DOI: https://doi.org/10.1016/j.cropro.2013.11.018

Butts TR, Samples CA, Franca LX, Dodds DM, Reynolds DB, Adams JW, Kruger GR (2018) Spray droplet size and carrier volume effect on dicamba and glufosinate efficacy. Pest management science 74(9): 2020-2029. DOI: https://doi.org/10.1002/ps.4913

Butts TR, Samples CA, Franca LX, Dodds DM, Reynolds DB, Adams JW, Luck JD (2019) Optimum Droplet Size Using a Pulse-Width Modulation Sprayer for Applications of 2,4-D Choline Plus Glyphosate. Agronomy Journal 111(3): 1425-1432. DOI:

https://doi.org/10.2134/agronj2018.07.0463

Creech CF, Henry RS, Fritz BK, Kruger GR (2015) Influence of herbicide active ingredient, nozzle type, orifice size, spray pressure, and carrier volume rate on spray droplet size characteristics. Weed technology 29(2): 298-310. DOI: https://doi.org/10.1614/WT-D-14-00049.1

Costa NV, Rodrigues ACP, Martins D, Cardoso LA, Silva JIC (2008) Efeito de pontas de pulverização na deposição e na dessecação em plantas de Brachiaria brizantha. Planta Daninha 26(4): 923-933. DOI: http://dx.doi.org/10.1590/S0100-83582008000400025

Dereumeaux C, Fillol C, Quenel P, Denys S (2020)

Pesticide exposures for residents living close to agricultural lands: A review. Environment international 134: 105210. DOI: https://doi.org/10.1016/j.envint.2019.105210

Duga AT, Delele MA, Ruysen K, Dekeyser D, Nuyttens D, Bylemans D, Verboven P (2017) Development and validation of a 3D CFD model of drift and its application to air-assisted orchard sprayers. Biosystems Engineering 154: 62-75. DOI:

https://doi.org/10.1016/j.biosystemseng.2016.10.010

Farias MAGL, Raetano CG, Chechetto RG, Ferreira-Filho PJ, Guerreiro JC, Bonini CS, Prado EP (2020) Spray nozzles and droplet size effects on soybean canopy deposits and stink bugs control in west region of São Paulo state-Brazil. Phytoparasitica 48: 1-11. DOI: https://doi.org/10.1007/s12600-020-00786-8 
Ferguson JC, O'Donnell CC, Chauhan BS, Adkins SW, Kruger GR, Wang R, Hewitt AJ (2015) Determining the uniformity and consistency of droplet size across spray drift reducing nozzles in a wind tunnel. Crop Protection 76: 1-6. DOI: https://doi.org/10.1016/j.cropro.2015.06.008

Ferguson JC, Chechetto RG, O’Donnell CC, Dorr GJ, Moore JH, Baker GJ, Powis KJ, Hewitt AJ (2016) Determining the drift potentials of Venturi nozzles compared to standard nozzles across three insecticide spray solutions in a wind tunnel. Pest management science 72(8):1460-1466. DOI: https://doi.org/10.1002/ps.4214

Ferguson JC, Chechetto RG, Adkins SW, Hewitt AJ, Chauhan BS, Kruger GR, O'Donnell CC (2018) Effect of spray droplet size on herbicide efficacy on four winter annual grasses. Crop Protection112: 118-124. DOI: https://doi.org/10.1016/j.cropro.2018.05.020

Ferguson JC, Chauhan BS, Chechetto RG, Hewitt AJ, Adkins SW, Kruger GR, O'Donnell CC (2019) Dropletsize effects on control of Chloris spp. with six POST herbicides. Weed Technology 33(1): 153-158. DOI: https://doi.org/10.1017/wet.2018.99

Ferreira EA, Procópio SO, Silva EAM, Silva AA, Rufino RJN (2003) Estudos anatômicos de folhas de espécies de plantas daninhas de grande ocorrência no Brasil: IVAmaranthus deflexus, Amaranthus spinosus, Alternanthera tenella e Euphorbia heterophylla. Planta Daninha 21(2): 263-271. DOI: https://doi.org/10.1590/S010083582003000200012 .

Grella M, Miranda-Fuentes A, Marucco P, Balsari P (2020) Field assessment of a newly-designed pneumatic spout to contain spray drift in vineyards: evaluation of canopy distribution and off-target losses. Pest Management Science 76(12): 4173-4191. DOI: https://doi.org/10.1002/ps.5975

Godinho-Jr JD, Vieira LC, Ruas RAA, Carvalho-Filho A, Faria VR, God PIVG (2020) Spray nozzles, working pressures and use of adjuvant in reduction of 2, 4-D herbicide spray drift. Planta Daninha 38: 1-7. DOI: https://doi.org/10.1590/s0100-83582020380100070

Knoche M (1994) Organosilicone surfactant performance in agricultural spray application: a review. Weed Research 34(3): 221-239. DOI: https://doi.org/10.1111/j.13653180.1994.tb01990.x

Massinon M, De Cock N, Forster WA, Nairn JJ, McCue SW, Zabkiewicz JA, Lebeau F (2017) Spray droplet impaction outcomes for different plant species and spray formulations. Crop Protection 99: 65-75. DOI: https://doi.org/10.1016/j.cropro.2017.05.003
Nairn JJ, Forster WA (2019) Due diligence required to quantify and visualise agrichemical spray deposits using dye tracers. Crop Protection 115: 92-98. DOI: https://doi.org/10.1016/j.cropro.2018.09.009

Nuyttens D, Baetens K, Schampheleire M, Sonck B (2007) Effect of nozzle type, size and pressure on spray droplet characteristics. Biosystems engineering 97(3): 333-345. DOI: https://doi.org/10.1016/j.biosystemseng.2007.03.001

Prado EP, Raetano CG, Dal Pogetto MHFA, Costa SIA, Christovam RDS (2015) Effects of silicone surfactant and application rates on spray deposition and soybean rust control. Engenharia Agrícola, 35(3): 514-527. DOI: https://doi.org/10.1590/1809-4430-Eng.Agric.v35n3p514$527 / 2015$

R development core team (2017) R: A Language and environment for statistical computing.

Rodrigues-Costa ACP, Martins D, Costa NV, Pereira MRR (2012) Aspectos quantitativos da deposição de gotas de pulverização em plantas de amendoim e Brachiaria plantaginea. Planta Daninha 30(1): 201-209. DOI: https://doi.org/10.1590/S0100-83582012000100023

Ritz C, Streibig JC (2012) Dose response curves and other nonlinear curves in Weed Science and Ecotoxicology with the add-on package drc in R. Disponível: www. bioassay. Dk. Accessed Abr 22, 2019.

Ritz C, Kniss AR, Streibig JC (2015) Research methods in weed science: statistics. Weed Science 63: 166-187. DOI: https://doi.org/10.1614/WS-D-1300159.1

Ruas RAA, Teixeira MM, Silva AAD, Fernandes HC, Vieira RF (2011) Estimativa de parâmetros técnicos da tecnologia de aplicação do glyphosate no controle de Brachiaria decumbens. Revista Ceres, 58(3): 299-304. DOI: http://dx.doi.org/10.1590/S0034737X2011000300009

Smith DB, Askew SD, Morris WH, Shaw DR, Boyette M (2000) Droplet size and leaf morphology effects on pesticide spray deposition. Transactions of the ASAE 43(2): 255-259. DOI: $10.13031 / 2013.2700$

Stainier C, Destain MF, Schiffers B, Lebeau F (2006) Droplet size spectra and drift effect of two phenmedipham formulations and four adjuvants mixtures. Crop protection 25(12): 1238-1243. DOI: https://doi.org/10.1016/j.cropro.2006.03.006

Tokura LK, Velini ED, Siqueira JAC, Alovisi AMT, Menezes MJS (2013) Efeito de pontas de pulverização e da palha de milheto na deposição da calda aplicada em plantas de Euphorbia heterophylla e Brachiaria plantaginea. Acta Iguazu 2(5): 35-44. DOI: http://saber.unioeste.br/index.php/actaiguazu/article/view/9162 